DOI: $10.33766 / 2524-0323.92 .325-334$

УДК 343.98

Ю. О. Комишнюк, аспірант Університету

Державної фіскальної служби України

(м. Ірпінь, Україна)

e-mail: komyshnyuk@i.ua

iDhttps://orcid.org/0000-0002-3484-3378

\title{
СУЧАСНИЙ СТАН ТА ПРОБЛЕМИ РОЗСЛІДУВАННЯ ЗЛОЧИНІВ У СФЕРІ ФІНАНСОВИХ РЕСУРСІВ ДЕРЖАВИ
}

Стаття присвячена проблемним питанням організації розслідування злочинів у сфері фінансових ресурсів держави, що потребують відповідних знань у галузі економіки, оподаткування, бухгалтерського обліку тощо.

3 урахуванням потреб практики розслідування злочинів та грунтуючись на статистичних даних правоохоронних органів, наведено низку факторів як об'єктивного, так і суб' єктивного характеру, що впливають на ефективність організації розслідування таких злочинів; запропоновано можливі напрями їх вирішення.

Наголошується на необхідності підбору якісного кадрового складу, який здатен розслідувати такі кримінальні правопорушення, його належної підготовки й підвищення кваліфікації.

Ключові слова: розслідування фінансових кримінальних правопорушень, фінансові ресурси держави, корупція, економіка, організована злочинність, фінансові процеси.

Постановка проблеми. Свроінтеграційний курс України зобов'язує забезпечувати ефективне функціонування інститутів, які гарантують верховенство права, дотримання прав та законних інтересів фізичних і юридичних осіб, їхній ефективний захист.

На сьогодні день правоохоронну функцію у сфері економічних правопорушень здійснюють податкова міліція, Служба безпеки України та Національна поліція України. За офіційними статистичними даними Офісу Генерального прокурора України, у 2019 році було зареєстровано 1287 кримінальних проваджень за ухилення від сплати податків. Водночас на стадії кримінального досудового розслідування в цьому році було закрито 262 кримінальні провадження, 3 яких 259 - за відсутності складу кримінального правопорушення. Результати судового розгляду відповідних кримінальних проваджень за вказаний період у Сдиному державному реєстрі судових рішень такі: із 18 вироків - 10 обвинувальних, із яких 3 - на підставі угоди про визнання винуватості, та 8 виправдувальних вироків [1].

Така статистика свідчить про недостатньо ефективну роботу в розслідуванні економічних злочинів, у першу чергу податкової міліції.

Аналіз останніх досліджень і публікацій. Проблеми протидії вчиненню кримінальних правопорушень в економічній сфері та фінансовій діяльності були предметом дослідження А. Ф. Волобуєва, В. Г. Гончаренка, В. К. Лисиченка, В. В. Лисенка, Г. А. Матусовского, Р. Л. Степанюка, С. С. Чернявського та ін. Заразом, попри (С) Комишннюк Ю. О., 2020 
значну кількість наукових праць, присвячених даній проблематиці, можна констатувати, що немає єдиного підходу до організації розслідування злочинів у сфері фінансових ресурсів держави.

Формулювання цілей. Метою даної статті є аналіз стану та проблем розслідування злочинів у сфері фінансових ресурсів держави та визначення напрямів ефективної роботи органів досудового розслідування.

Виклад основного матеріалу. Фінанси відіграють провідну роль в економічній системі держави. Це зумовлено тим, що при їх функціонуванні визначаються якісні й кількісні параметри будь-якого економічного явища чи процесу. Обов' язковим елементом участі фінансів в економіці держави, підприємництва чи громадянина є грошові кошти. Без використання грошових коштів у процесах виробництва здійснення державою своїх функцій, задоволення населенням своїх потреб немає фінансів. Вони повинні забезпечити ефективне формування та використання фондів фінансових ресурсів як на макро-, так і на мікрорівнях для успішного здійснення господарської діяльності, виконання державою своїх функцій в економічній діяльності.

Фінансові ресурси - це грошові фонди, які створюються в процесі розподілу, перерозподілу й використання валового внутрішнього продукту, що створюється впродовж певного часу в державі. Фінансові ресурси держави включають ті з них, що перебувають у розпорядженні органів державного управління, усіх видів і форм підприємництва, а також населення. У розпорядженні держави перебувають ресурси бюджетної системи й різних видів централізованих і децентралізованих фондів, а також державних фінансових інститутів. Інша частина фінансових ресурсів у державі перебуває в розпорядженні господарських підприємств, установ й організацій різних форм власності та видів діяльності. Третя частина - у розпорядженні населення в формі вкладів, заощаджень і депозитів у банківській системі та в інших фінансових установах [2, с. 81].

Враховуючи вищевикладене, можна запропонувати таке визначення поняття «фінансові ресурси держави»: це грошові кошти, які створюються й перебувають в розпорядженні держави, суб'єктів господарювання та населення й трансформуються через відповідні фонди у фінансові ресурси держави з метою виконання нею ії основних функцій.

Основним способом збагачення в Україні був і залишається прямий або опосередкований перерозподіл державних коштів, засобів та майна, що відбувається шляхом законних операцій (обслуговування державних цільових програм, приватизація державних підприємств, отримання дотацій з державного бюджету тощо) або в незаконний спосіб. Незаконною така діяльність стає через виведення з обігу або розкрадання матеріальних засобів і фінансових ресурсів (нецільове використання бюджетних коштів, неправомірне відшкодування ПДВ, завищення цін на товари та послуги, які надаються державі, проведення фіктивних аукціонів із державним майном тощо). У будь-якому разі така діяльність пов'язана 3 корупцією, різними схемами ухилення від оподаткування та виведення грошових коштів в офшорні зони [3, с. 129].

Аналіз судово-слідчої практики, чинного законодавства дає підстави вважати, що розслідування злочинів, пов' язаних із фінансовими ресурсами держави, 
ускладнюється недосконалістю банківського та кримінального законодавства, суперечливістю судової практики, відсутністю досвіду в білышості слідчих та оперативних працівників, відсутністю комплексних методик і навчальних тренінгів для працівників правоохоронної системи, які займаються розслідуванням злочинів у фінансовій сфері держави.

Важливе значення для розслідування даної категорії кримінальних правопорушень має взаємодія контролюючих і правоохоронних органів. До чинної системи органів, які забезпечують фінансову безпеку держави входять Національна поліція України, Служба безпеки України, податкова міліція, прокуратура, Національне антикорупційне бюро України, Державна служба фінансового моніторингу України, Державна аудиторська служба України, Рахункова палата [1].

Однак, незважаючи на таку розгалужену систему органів, їх робота є вкрай не ефективною, через те що: існує низький рівень взаємодії між контролюючими і правоохоронними органами; відсутня єдина інформаційна база даних; відчутна конкуренція правоохоронних органів між собою та існує вплив на них із зовнішнього боку; діють застарілі методики в розслідуванні та обробці інформації в даній категорії кримінальних правопорушень; панує низька взаємодія між національними і зарубіжними правоохоронними органами в розслідуванні економічних злочинів; відсутні спеціалізовані судово-експертні установи з проведення економічних і дотичних до них експертиз.

Важливе значення має той факт, що здебільшого злочини, пов' язані з фінансовими ресурсами держави, вчиняються групою осіб та організованими злочинними групами, які мають розгалужену мережу не тільки в Україні, а й за кордоном. Організаторами виступають особи, які володіють суттєвими економічними знаннями, практичним досвідом, мають зв' язки в апараті державної влади і здатні замаскувати і підготувати вчинення подібних злочинів. Такі особи вчиняють кримінальні правопорушення без застосування насильства, а завдяки своїм розумовим здібностям, із використанням неправдивих відомостей і за допомогою структурованих злочинних організацій по виведенню і конвертації коштів [5, с. 231; 6, с. 24 ].

Фінансові розслідування необхідні для боротьби зі злочинщями шляхом вивчення їхнього бізнесу: 3 наркоторгівлі, організованої злочинної діяльності, відмивання коштів або банківського шахрайства. Вивчення руху грошових коштів може посприяти виявленню лідерів злочинних організацій. Однак фінансові розслідування є надзвичайно складними видом розслідувань. По-перше, для їх здійснення необхідним є багаторічний досвід роботи у фінансовій сфері; по-друге, самостійними зусиллями жодне відомство не в змозі охопити широкий спектр інформації, необхідної для відстеження всіх фінансових операцій; по-третє, великий розмір, різноманітність та постійні зміни у фінансовому секторі роблять фінансові розслідування все білыш складними. Інструментарій з відмивання коштів, що складається із фінансових операцій із використанням переказів мережею інтернет стає все більш винахідливим. Як тільки правоохоронні органи дізнаються про зміст нової технології з відмивання коштів і вживають заходів $з$ протидії, злочинщі змінюють схему на іншу, більш вишукану і складнішу [7, с. 9]. 
Зазначені обставини більшою мірою зумовлюють коло значущих проблем, пов 'язаних із забезпеченням ефективного виявлення і розслідування даної категорії злочинів.

Результати проведеного дослідження показують, що однією з основних проблем можна вважати недостатню забезпеченість осіб, які здійснюють виявлення та розслідування зазначеного кримінального правопорушення науково обгрунтованими методико-криміналістичними рекомендаціями. Насамперед це стосується криміналістичних рекомендацій, які повинні бути не тільки затребуваними, тобто мати практичну цінність, але й своєчасними, а значить, іти на крок швидше за злочинність. Через часті зміни в кримінальному процесуальному законодавстві перед дослідниками стоїть складне завдання - розробити й удосконалити необхідні методики розслідування фінансових злочинів 3 метою максимального забезпечення потреб правоохоронних органів у протидії злочинам, пов'язаним із фінансовими ресурсами держави.

Існуючі методики орієнтовані на розслідування тільки одного виду кримінальних правопорушень, тим самим фактично не дозволяють скласти цілісне уявлення про найбілыш істотні ознаки відповідної криміналістично однорідні групи діянь, установити загальні закономірності як у способах вчинення таких діянь, так і в методах їх розслідування. Дана обставина обумовлює необхідність теоретичного дослідження окремих видів кримінальних правопорушень, об'єднання їх у групи і розроблення практичних рекомендацій щодо їх розслідування [8, с. 186; 9, с. 180].

Аналіз судово-слідчої практики дозволяє стверджувати, що успіх розслідування фінансових злочинів значною мірою залежить від рівня організащії роботи і від уміння аналізувати інформацію як орієнтуючого, так і доказового характеру. Доцільно зазначити, що деякі слідчі, не маючи достатнього досвіду роботи, помилково вважають, що розкриттям і виявлення ознак злочинів, пов'язаних з фінансовими ресурсами держави, повинні займатися працівники оперативних підрозділів, а на частку слідчого залишається лише процесуальне закріплення отриманих у результаті оперативної діяльності доказів. Це є дуже велика помилка. У більшості випадків на момент початку досудового розслідування слідчий володіє обмеженим обсягом інформації про обставини кримінального правопорушення. Нерідко в процесі досудового розслідування докорінно змінюється уявлення не лише про спосіб і механізм вчинення злочину, його виконавців, але навіть кваліфікації скоєного [10, с. 45].

До зазначеного необхідно додати, що при розслідуванні злочинів, пов'язаних із фінансовими ресурсами держави, важливо враховувати особливості фінансового законодавства (банківського, господарського, податкового тощо). Без розуміння механізмів функціонування фінансових процесів у державі в цілому і iї складових окремо, зокрема порядку реєстрації суб'єктів господарювання, руху коштів між фінансовими установами, порядку нарахування обов'язкових платежів та зборів, функціонування податкової системи тощо, не можна висувати версії про вид і місцезнаходження слідів кримінального правопорушення, про володіння злочинцем певними професійними навичками, визначення характеру і способів підготовки, вчинення та приховування діяння і, як наслідок, зібрати докази для 
викриття винних і розслідування злочину. Можна стверджувати, що без урахування наведених обставин, і не тільки, у більшості ситуацій неможливо прийняти правильне рішення за результатами розслідування, та й сам процес розслідування може здійснюватися не в потрібному напрямку [5, с. 187].

Будь-яке розслідування розпочинається з аналізу вихідної інформації, що міститься в матеріалах, які стали підставою для прийняття рішення про початок досудового розслідування, а саме: у матеріалах проведеної перевірки (різного роду документів, довідок, ревізійних перевірок тощо). В отриманих документах може бути певна інформація про спосіб вчинення кримінального правопорушення, розмір матеріального збитку, можливих виконавців, шляхи виведення коштів. Однак, це не означає, що розслідування кримінального правопорушення буде швидким і легким, оскільки можуть виникнути труднощі в конкретизації способу вчинення, визначення кола учасників, механізмів виведення коштів і шляхів їх повернення тощо [11].

Зазвичай матеріали перевірки заяв чи повідомлень про можливе вчинення кримінального правопорушення містять значний обсяг інформації, особливо якщо описуване діяння мало тривалий строк існування або якщо в ньому задіяна велика кількість осіб із різних підприємств, установ чи організацій, а також коли було застосовано заходи, спрямовані на приховування таких протиправних дій. Окрім пояснень обізнаних осіб, у них містяться установчі, бухгалтерські, нормативні документи, акти інвентаризацій, ревізій чи перевірок, різні довідки, накладні та інші джерела про вчинення кримінального правопорушення. Правильна оцінка наявної інформації можлива лише на основі повного та всебічного аналізу зібраних матеріалів [3, с. 85].

Основним завданням такого аналізу є: належна оцінка, систематизація, структуризація інформації; своєчасне і правильне використання відомостей, які має слідчий; висунення версій; визначення завдань розслідування і пошук необхідних доказів.

При опрацюванні визначених завдань важливе значення мають методи аналізу наявної в провадженні інформації, організації пошуку нових даних. Як показує аналіз судово-слідчої практики, однією з причин низької якості розслідування кримінальних правопорушень, пов'язаних із фінансовими ресурсами держави, $є$ неправильний вибір, а іноді - і незнання методів організації розслідування, оцінки та використання наявної інформації, невміння визначати завдання і знаходити шляхи їх вирішення. Більшість слідчих, які займаються розслідування злочинів фінансового спрямування відчувають труднощі при аналізі первинних даних і інформації вузького спрямування, яка потребує залучення спеціаліста в даному напрямку. Зазвичай такі завдання зводяться до однієї, рідше - двох слідчих версій та обмежуються загальними міркуваннями про необхідність встановити місце, час, спосіб вчинення кримінального правопорушення, можливих співучасників. Такий результат є закономірністю невмінням правильного аналізу вихідної інформації [5, с. 376].

Невміння виділити основні ознаки початкової інформації, криміналістичні ознаки кримінального правопорушення, взаємозв' язки між окремими фактами, характер та обсяг недостатніх відомостей, які необхідно отримати або уточнити, 
призводить до того, що слідчі, особливо на початковому етапі, проводять слідчі (розшукові) дії безсистемно і нецілеспрямовано, тому припускаються безлічі помилок, які призводять до затримки в розслідуванні або взагалі до зведення його нанівець.

Зазначені вище та інші методи наукового аналізу наявної в розпорядженнях слідчого інформації дозволяють оптимізувати процес пошуку ознак злочинного діяння, визначення всіх можливих версій, сприяють правильному формулюванню загальних та окремих завдань розслідування, створюють умови для розробки оптимального плану як розслідування в цілому, так і виконання окремих слідчих (розшукових) та негласних слідчих (розшукових) дій. Такий аналіз дозволяє використовувати не лише особистий досвід учасника кримінального провадження, але й науковий потенціал криміналістики, кримінології, кримінальноправових та інших наук для всебічного, повного та об'єктивного дослідження всіх обставин злочину [11].

Розслідування злочинів із фінансовими ресурсами держави не можливе без участі спеціалістів різних галузей знань: банківської сфери, бухгалтерського обліку, податкового законодавства, комп'ютерних технологій тощо. Участь спеціаліста при розслідуванні даної категорії злочинів найбілыш поширена при проведенні обшуків, у ході допиту, призначенні експертиз тощо. Особливо важлива участь спеціаліста при проведенні обшуку і вилученні документації, комп'ютерної техніки тощо.

Вилучені матеріали в обов'язковому порядку мають бути передані для подальшого вивчення в експертних установах, які займаються дослідженням даної категорії проваджень і володіють спеціальними знаннями і методиками для проведення таких експертиз. Отримані експертні висновки дають можливість краще зрозуміти механізм вчинення даної категорії злочинів і вдосконалити план проведення слідчих (розшукових) дій із розкриття конкретних злочинів.

Для впровадження дієвої реформи у сфері протидії кримінальним загрозам у сфері фінансової безпеки в Україні назріла необхідність створити єдиний правоохоронний орган, завданням якого буде виявлення та усунення системних загроз у сфері публічних фінансів, запобігання їх виникненню в майбутньому. Цей орган має стати єдиним аналітичним центром концентрації та аналізу інформації про стан фінансової системи держави, що збирається держаними органами та органами самоврядування, а головне - створити підгрунтя для переходу державних контролюючих органів від наглядово-каральної до профілактично-сервісної моделі роботи [12, с. 8-10].

Створення нового органу з фінансових розслідувань - ідея, яка обговорюється майже п' ять років, але так і залишається на словах. Законопроекти, які були створені для формування нового органу, не пройшли голосування у Верховній Раді України та навіть через комітети. 3 огляду на це, можна стверджувати, що законодавець або особи, яких лобіюють народні депутати, намагаються відтягнути процес створення нового органу з розслідування злочинів, пов' язаних із фінансовими ресурсами держави. Новий орган має замінити податкову міліцію, яка 31 січня 2017 р. виявилася фактично поза законом: депутати помилково виключили 
3 Податкового кодексу України положення про податкову міліцію. Створення нового органу має посприяти розслідуванню злочинів в економічній сфері і зосередити цей процес у «руках» одного органу, який і має стати «стрижнем» боротьби 3 організованою злочинністю в економічній сфері й всіма доступними методами протидіяти вчиненню даної категорії злочинів як на території країни, так і за іï межами. Міжнародна співпраця повинна бути налагоджена на державному рівні, з метою поглиблення взаємодії в розкритті і попередженні даних злочинів.

Висновки. Складність та специфічність злочинів, вчинених з фінансовими ресурсами держави, потребують відповідної підготовки слідчих та вміння ними здійснювати глибокий аналіз бухгалтерської, податкової, фінансової звітності, а також залучення, у разі необхідності, висококваліфікованих фахівців із указаних галузей. Належній організації розслідування таких злочинів сприяє налагодження ефективних взаємозв'язків між правоохоронними і контролюючими органами, обмін наявною інформацією, створення та наповнення відповідних інформаційних банків даних.

Держава намагається протистояти вчиненню таких злочинів, зокрема, через створення органів, які здійснюють фінансовий моніторинг, розслідування фінансових та корупційних злочинів (Національне антикорупщійне бюро України тощо), здійснення відкритих торгів на ресурсі «Прозоро» та інші кроки в даному напрямі. Однак, як свідчить практика, ситуація у сфері фінансових ресурсів держави залишається вкрай складною. Правопорушники постійно змінюють напрями та зміст злочинної діяльності, розробляють інноваційні механізми приховування їі слідів. Зазначене вище, відповідно, вимагає належної організації діяльності з виявлення та розслідування таких злочинів, підготовки кадрового складу правоохоронних органів, які б могли протидіяти їх вчиненню.

\section{Використані джерела:}

1. Пояснювальна записка до проекту Закону України «Про бюро економічної безпеки України». URL : http://w1.c1.rada.gov.ua/pls/zweb2/webproc4_1?pf3511=69331. (дата звернення: 04.11.2020).

2. Василик О. Д. Теорія фінансів. Київ : НІОС, 2000. 416 с.

3. Лисенко В. В. Проблеми та перспективи удосконалення протидії діяльності суб'єктів господарювання з знаками фіктивності : монографія. Київ : Алерта, 2012. 298 с.

4. Охрімчук Т. В. Криміналістична характеристика шахрайства з фінансовими ресурсами та основні напрями розслідування : автореф. канд. юрид. наук: 12.00.09. Національна академія внутрішніх справ, 2011. 16 с.

5. Теоретичні та практичні основи методики розслідування фінансового шахрайства: дисертація доктора юрид. наук: 12.00 .09 / Чернявський Сергій Сергійович / Національна академія внутрішніх справ, 2010. 610 с.

6. Білоус В. Т. Координація управління правоохоронними органами України по боротьбі з економічною злочинністю (адміністративно-правовий аспект) : автореферат дис... .-ра юрид. наук: спеціальність 12.00.07 / Нац. ун-т внутр. спр. України. Харків, 44 c. URL : http:/ / www.irbis-nbuv.gov.ua. (дата звернення: 04.11.2020).

7. Важинський В. М. Процес доказування при розслідуванні фіктивного підприємництва та пов' язаних з ним злочинів в Україні : автореф. ...канд. юрид. наук: 12.00.09. Київський національний університет імені Тараса Шевченка. Київ, 2009. 19 с. 
8. Бахин В. П. Криминалистика. Проблемы и мнения (1962-2002 гт.). Киев, 2002. 268 с.

9. Криміналістична тактика : навч. посіб. / за ред. д-ра юрид. наук, проф. М. А. Погорецького та д-ра юрид. наук, доцента Л. Б. Сєргєєвої. 2-ге вид., перероб, та доп. Київ: Алерта. 244 с.

10. Довбаш Р. С. Методика розслідування злочинів, пов'язаних з незаконним відшкодуванням податку на додану вартість : дис. кандидата юрид. наук: 12.00.09. Київський національний університет внутрішніх справ, 2009. 253 с.

11. Про оперативно-розшукову діяльність: Закон від 18.02.1992 № 2135-XII. Дата оновлення: 24.10.2020. URL : https://zakon.rada.gov.ua/laws/show/2135-12\#Техt. (дата звернення: 04.11.2020).

12. Беззуб I. Проблеми та перспективи створення Національного бюро фінансової безпеки в Україні. Громадська думка про правотворення. 2018. № 7 (151). C. 6-13. URL : http:/ /nbuviap.gov.ua/images/dumka/2018/7.pdf. (дата звернення: 04.11.2020).

\section{References:}

1. Poiasniuvalna zapyska do proektu Zakonu Ukrainy «Pro biuro ekonomichnoi bezpeky Ukrainy». N.d.N.p. URL: http://w1.c1.rada.gov.ua/pls/zweb2/webproc4_1?pf35 11=69331. [in Ukrainian].

2. Vasylyk, O. D. (2000) Teoriia finansiv. Kyiv : NIOS. [in Ukrainian].

3. Lysenko, V. V. (2012) Problemy ta perspektyvy udoskonalennia protydii diialnosti sub'iektiv hospodariuvannia z znakamy fiktyvnosti : monohrafiia. Kyiv : Alerta. [in Ukrainian].

4. Okhrimchuk, T. V. (2011) Kryminalistychna kharakterystyka shakhraistva z finansovymy resursamy ta osnovni napriamy rozsliduvanni. Extended abstract of candidate's thesis. Natsionalna akademiia vnutrishnikh sprav. [in Ukrainian].

5. Cherniavskyi, S. S. (2010) Teoretychni ta praktychni osnovy metodyky rozsliduvannia finansovoho shakhraistva. Doktor's thesis. Natsionalna akademiia vnutrishnikh sprav. [in Ukrainian].

6. Bilous, V. T. (2007) Koordynatsiia upravlinnia pravookhoronnymy orhanamy Ukrainy po borotbi z ekonomichnoiu zlochynnistiu (administratyvno-pravovyi aspekt): Extended abstract of Doktor's thesis. Nats. un-t vnutr. spr. Ukrainy. Kharkiv. URL: http://www.irbis-nbuv.gov.ua. [in Ukrainian].

7. Vazhynskyi, V. M. (2009) Protses dokazuvannia pry rozsliduvanni fiktyvnoho pidpryiemnytstva ta pov'iazanykh z nym zlochyniv v Ukraini. Extended abstract of candidate's thesis. Kyivskyi natsionalnyi universytet imeni Tarasa Shevchenka. Kyiv, 2009. 19 p. [in Ukrainian].

8. Bakhyn V.P. Krymynalystyka. Problemi y mnenyia (1962-2002). Kyiv. [in Ukrainian].

9. Kryminalistychna taktyka: navch. posib. M. A. Pohoretskii, \& nauk, dotsenta L. B. Sierhieieva (Eds.). 2-he vyd., pererob. ta dop. N. d. Kyiv : Alerta. [in Ukrainian].

10. Dovbash, R. S. (2009) Metodyka rozsliduvannia zlochyniv, pov'iazanykh z nezakonnym vidshkoduvanniam podatku na dodanu vartist. Candidate's thesis. Kyivskyi natsionalnyi universytet vnutrishnikh sprav. [in Ukrainian].

11. Pro operatyvno-rozshukovu diialnist: Zakon vid 18.02.1992 № 2135-XII. Data onovlennia: 24.10.2020. (2020) N. p. URL : https://zakon.rada.gov.ua/laws/show/2135-12\# Text. [in Ukrainian].

12. Bezzub, I. (2018) Problemy ta perspektyvy stvorennia Natsionalnoho biuro finansovoi bezpeky v Ukraini. Hromadska dumka pro pravotvorennia - Public opinion on lawmaking, 7(151), 6-13. URL: http://nbuviap.gov.ua/images/dumka/2018/7.pdf. [in Ukrainian]. 
Комишнюк Ю. А., аспирант Университета Государственной фискальной службы Украины

(г. Ирпень, Украина)

\section{СОВРЕМЕННОЕ СОСТОЯНИЕ И ПРОБЛЕМЫ РАССЛЕДОВАНИЯ ПРЕСТУПЛЕНИЙ В СФЕРЕ ФИНАНСОВЫХ РЕСУРСОВ ГОСУДАРСТВА}

Статья посвящена проблемным вопросам организации расследования преступлений в сфере финансовых ресурсов государства, требующих соответствующих знаний в сфере экономики, налогообложения, бухгалтерского учета и тому подобное.

С учетом потребностей практики расследования преступлений, и основываясь на статистических данных правоохранительных органов, приведен ряд факторов как объективного, так и субъективного характера, влияющих на эффективность организации расследования таких преступлений; также предложены возможные направления их решения.

Подчеркивается необходимость подбора качественного кадрового состава, способного расследовать такие уголовные преступления, его надлежащей подготовки и повьшения квалификации.

Ключевые слова: расследование финансовых уголовных правонарушений, финансовые ресурсы государства, коррупция, экономика, организованная преступность, финансовые процессы.

Komyshniuk Yu., Post-Graduate of University of State Fiscal Service of Ukraine (Irpin, Ukraine)

\section{THE CURRENT STATUS AND PROBLEMS OF INVESTIGATION OF CRIMES IN THE FIELD OF FINANCIAL RESOURCES OF THE STATE}

The article is devoted to the problematic issues of the organization of the crime investigation process in sphere of state financial resources. Financial resources are the basis of the state.

The views of scientists who have studied this issue and concluded that the investigation of economic and financial crimes is a very complex and troublesome process that requires knowledge of economics, taxation, accounting and more. The works of domestic and foreign scientists prove that financial crimes are a complex mechanism that is developed and honed over the years. Scientific works are aimed at establishing ways to spread and counteraction financial crimes at both national and international levels.

The article presents the current state of the investigation, which is based on statistical data given by law enforcement agencies of this category of crimes. Problems that arise in law enforcement agencies during investigative (search) and covert investigative (search) activities and possible ways to solve them. Investigating financial crimes is a very complex and troublesome process. Law enforcement agencies dealing with this category of cases should always be one step ahead of criminal groups that commit these crimes. Due to certain circumstances, 
regulatory and law enforcement agencies can't catch up the development of ways and means of concealing financial crimes. Each time they become more confusing and complex. Regulators and law enforcement agencies have to involve more specialists not only in law enforcement but also in various areas of finance.

The article also considers the need to pay more attention to this category of crimes and training specialists who are able to investigate them in accordance with current legislation and within the timeframe provided by law. There is a question of creation of the single law enforcement agency which would be engaged in investigation of financial crimes in the state. This agency should carry out both law enforcement and analytical work. It must absorb the powers of the agencies that exist today and become a kind of outpost of country's economic security.

Keywords: investigation of financial criminal offenses, financial resources of the state, corruption, economy, organized crime, financial processes. 